\title{
シクロヘキサンの液相酸化によって生成する シクロヘキサノンの品質についで*
}

\author{
松 波 泰 造**
}

by Taizo Matsunami**

\author{
Regarding the Qualities of Cyclohexanone Produced by \\ Liquid Phase Oxidation of Cyclohexane*
}

\begin{abstract}
Summary : The qualities of cyclohexanone and cyclohexanol, produced from cyclohexane, by method of liquid phase oxidation, were investigated by gas chromatography and ultra-violet absorption spectrography, in order to confirm whether the cyclohexanone obtained from oxidation process could be used for the production of nylon 6.

Experiments were performed with both saponified and unsaponified samples and the following results were obtained:

1. The gas chromatographic results of cyclohexanone and cyclohexanol produced by oxidation showed no difference from that of cyclohexanone and cyclohexanol produced from phenol.

2. The data indicated by the ultra-violet absorption spectrographic test of cyclohexanone produced by oxidation proved different from that of cyclohexanone produced from phenol by $230 \mathrm{~m} \mu$ wave length.

3. After saponification, or the rectification of the samples, the ultra-violet absorption spectrographic results were found to be the same.
\end{abstract}

\section{1. 緒言}

筆者はシクロヘキサンの液相酸化の際にンクロヘキサノン・ シクロヘキサノールとともに $\mathrm{C}_{6}$ 以下の一塩基性脂肪酸扰よび 二䀅基性脂肪酸が生成することを知った”， から有機酸ならびに有機酸のエステルを除去する好理を行なっ た後、精密蒸留とよってシクロヘキサノン・シクロヘキサノー ル留分をとり、この留分の品質をつェノール法のるのと比較し た。

すなわちシクロヘキサンの液相酸化によって得られるシク口 ヘキサノン・シクロヘキサノール留分はフェノール法から得ら れるるのと異なる不純物を含んでいるので特別な精製法を用い なければを-カプロラクタムの原料として用いられないのでは ないかとの懸念があったので），この点を検刢するためガスク ロマトグラフ邨び紫外線スペクトルを用いて実験を行なっ た。

\section{以下その結果について報告する。}

\section{2. 実験}

2.1 試料

。酸化シクロヘキサノン・シクロヘキサノール

注1) シクロヘキサンの液相酸化によってシクロへキサハン・シクロへ キサノールを製造する場合の最適反応条件と考えられる, 反応温 度 $150^{\circ} \mathrm{C}$, 反応在 $14 \mathrm{~atm}$, 全反応率 $9 \mathrm{~mol} \%$ の条件でパイロット ブラントを運転して得られた試料で石油誌, 4,620 (1961) の実験 に使用したと同一のものである。

$*$ 昭和 36 年 5 月 21 日受理

** 宇部興産株式会社
パイロットプラントで得られた反応生成物注1)（全反応率約

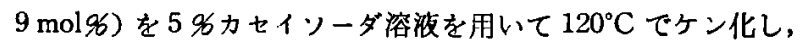
水洗後ウィットマー型蒸留装置を用いて末反応シクロヘキサン 分 $\left(\sim 140^{\circ} \mathrm{C}\right)$ を追出した。 $140^{\circ} \mathrm{C}$ 以上の留分は島津製高温ポ ドビルニアク精密分留装證を用いて前留分 $\left(\sim 140^{\circ} \mathrm{C}\right)$, 主留分 $\left(140 \sim 164^{\circ} \mathrm{C}\right)$, 後留分 $\left(164 \sim 170^{\circ} \mathrm{C}\right)$, 力又残 $\left(170^{\circ} \mathrm{C}\right.$ 食上) に分け、主留分を酸化シクロヘキサノン・シクロヘキサノール とした。

○酸化精シクロヘキサノン

酸化シクロヘキサノン・シクロヘキサノールをさらに精密蒸 留しシクロヘキサノン純度が $98 \mathrm{wt}$ \%

○酸化末ケン化シクロヘキサノン

パイロットプラントで得られた反応生成物から5\%力ャイン 一ダ溶液を用いて有嘰酸をとりのぞき，水洗後ウィットマー型 蒸留装置を用いて未反応シクロヘキサン分 $\left(\sim 140^{\circ} \mathrm{C}\right)$ を追出 した。1 $140^{\circ} \mathrm{C}$ 以上の留分は皛津製高温ポドビルニアク精密分留 装置を用いて前留分 $\left(\sim 140^{\circ} \mathrm{C}\right)$, 主留分 $\left(140 \sim 164^{\circ} \mathrm{C}\right)$, 後留 分 $\left(164 \sim 170^{\circ} \mathrm{C}\right)$, 力又残 $\left(170^{\circ} \mathrm{C}\right.$ 以上) K分け, 主留分をさ らに精密分留し，酸化未ケン化シクロヘキサノンを得た。

○酸化末ケン化精シクロヘキサノン

酸化未ケン化シクロヘキサノンをさらに精密分留したるので ある。

・フェノール法シクロヘキサノン

宇部興産株式会社宇部カプロラクタム工場製の粗シクロへキ サノン、精留シクロヘキサノンをそれぞれ武料とした。これら 試料の純度は

粗シクロヘキサノン $85 \%$ 
精留シクロヘキサノン 99.3\%

○フェノール法シクロヘキサノール

宇部興産株式会社宇部カプロラクタム工第製の精留シクロヘ キサノールを試料とした。

○ エステル類

シクロヘキシルギ酸エステル, シクロヘキシル釄酸エステ ル、シクロヘキシル酪酸エスルはシクロヘキサノールとそれ ぞれの酸とを常法によってエステル化し，精留によって分留し エステル価と沸点の合致する留分を試料とした。ギ酸・酢酸は 試薬を用いた。

\section{2 实臤方法}

i) ガスクロマトケラフ

島津製 GC-1 A 型ガスクロマトグラフ装を用いた。カラ ムはポリエチレングリコール No. 6000 の $1.5 \mathrm{~m}$ のbのを使 用しキャリアーガスはヘリウムを用いた。

ii）莱外部吸収スベクトル

島津製 UV スペクトロメーターを使用し水晶セルを用いて 测定した。

\section{3. 結果および考察}

i） ガスクロマトグラフ

試料をガスクロマトグラフとかけた結果を表 1 亿示した。

\begin{tabular}{|c|c|c|}
\hline 試 & 図 & 番 号 \\
\hline シクロヘキシルキ酸エステル & & 図 1 \\
\hline シクロヘキシル酶酸エステル & & $n$ \\
\hline シクロヘキシル酪酸エステル & & $n$ \\
\hline フェノール法シクロヘキサノール & & $n$ \\
\hline 酸化生成物の前留分 & & 図 2,3 \\
\hline - の主留分 & & 図 4,5 \\
\hline " の後留分 & & 图 6,7 \\
\hline " のカマ䄀 & & 図 8,9 \\
\hline
\end{tabular}

図1,図3からわかるようにシクロへキ甘ノンとシクロへキ シルギ酸エステルとは山が接近してあらわれるので微量のエス テルがシクロヘキサノン中に含まれている場合にはガスクロマ トグラフでは確認し觀いが，酸化シクロヘキサノン・シクロヘ キサノール留分のガスクロマトグラフでは頖著な不紝物のピー クは認められなかった。

ii）紫外部吸収スペクトル

武料の紫外吸取スペクトルをとった結果を表 2 に示した。

末ケン化シクロヘキサノンは䤄化シクロヘキサノン・シクロ

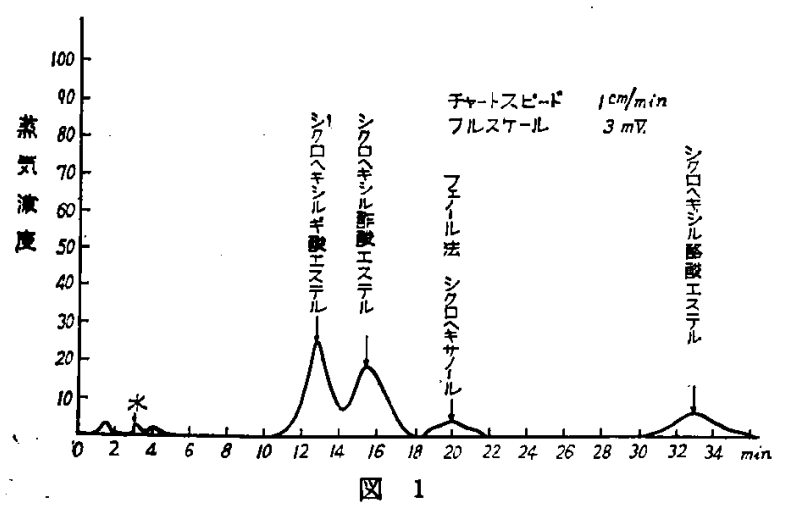

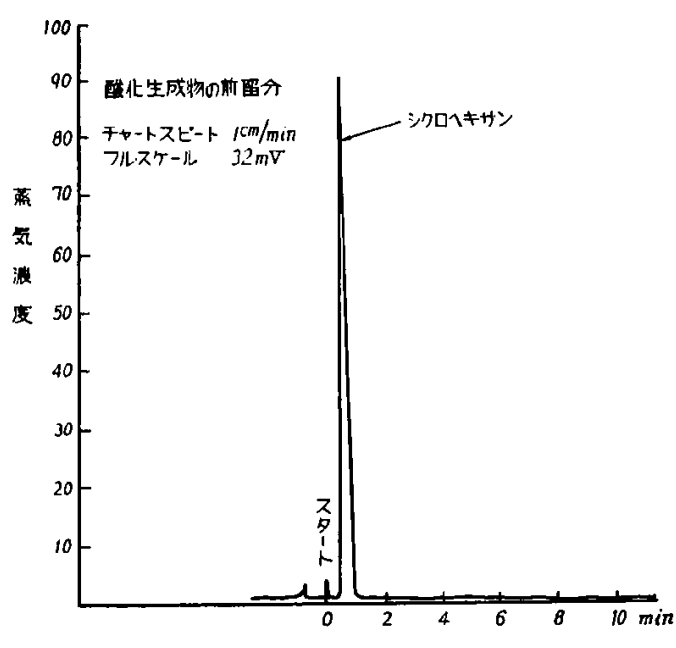

図 2

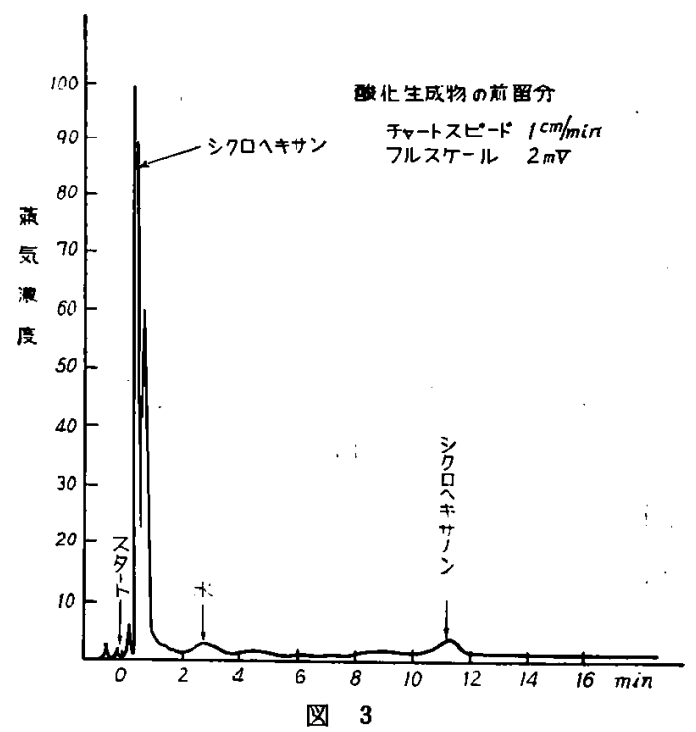

ヘキサノールK比ベシクロヘキサノン含有量が高いにもかかわ らず,酸価・ケン化価が大きく，かつ吸収スペクトルも図 13 と图 14 とを比較してかかるように $230 \mathrm{~m} \mu$ の波長に特異 の吸収が表われる。これは図18から推定してシクロへキサ， 一ルの有機醂エステルではないかと考元られる。図16から見 て $230 \mathrm{~m} \mu$ に特異の吸收を示す物筫は高沸部に存在することが わかり，シクロヘキサノールの有機酸エステルによって未ケン 表 2

\begin{tabular}{|c|c|c|c|c|}
\hline \multirow{2}{*}{ 試 } & \multicolumn{3}{|c|}{ 分 析 值 } & \multirow{2}{*}{ 図番号 } \\
\hline & 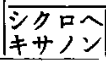 & 酸 価 & 华価 & \\
\hline フニノール法精シクロヘキサノール & & & & 図10 \\
\hline フニノール法精シクロヘキサノン & $99.3 \%$ & & & 図11 \\
\hline フニノール法粗シクロヘキサノン & $85.0 \%$ & & & 因12 \\
\hline ヘキサノン・シクロヘキサ & $52.0 \%$ & 0.062 & 3.30 & 图13 \\
\hline 酸化精シクロヘキサノン & $98.0 \%$ & & & 図17 \\
\hline 酸化未ケン化シクロヘキサノン & $94.9 \%$ & 1.2 & 10.8 & 四14 \\
\hline 酸化未ケン化精シクロヘキサノン & $98.7 \%$ & 0.2 & 5.1 & 因15 \\
\hline 酸化未ケン化シクロヘキサノン蒸留残 & $74.4 \%$ & 6.3 & 33.7 & 図16 \\
\hline シクロヘキシルキ酸エステル & & & & 図18 \\
\hline シクロヘキシル䣴酸エステル & & & & $n$ \\
\hline シクロヘキシル酪酸エステル & & & & n \\
\hline
\end{tabular}



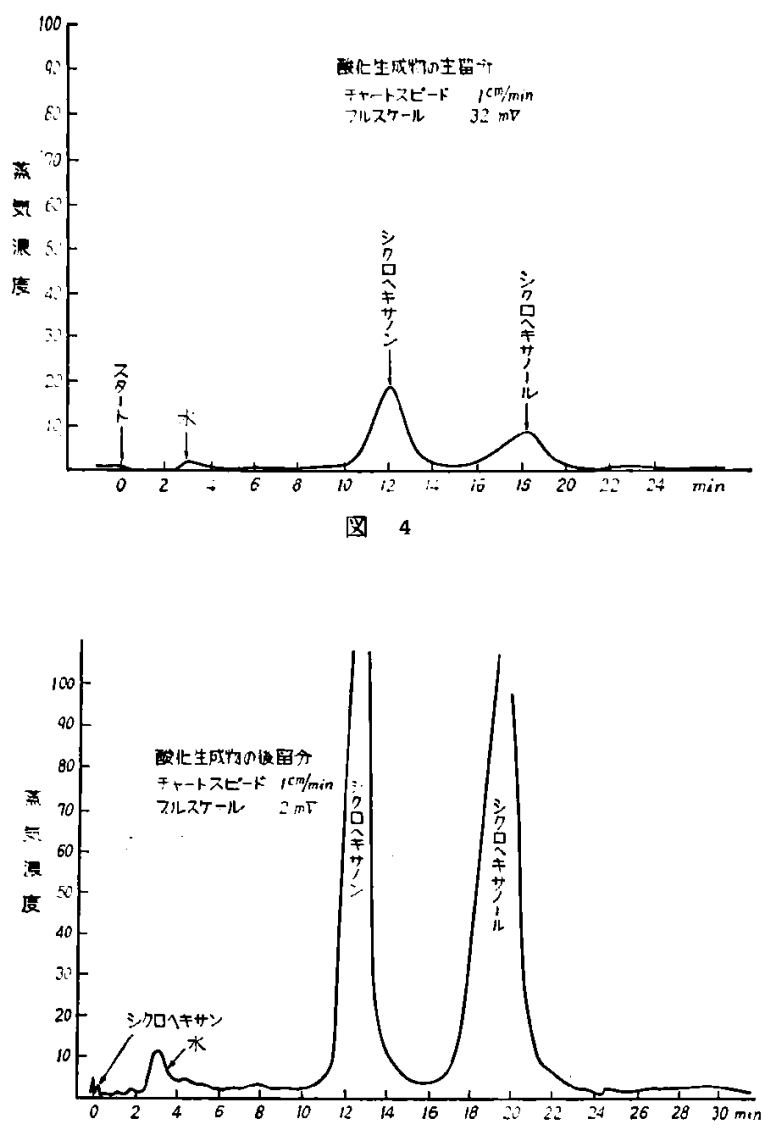

図 5

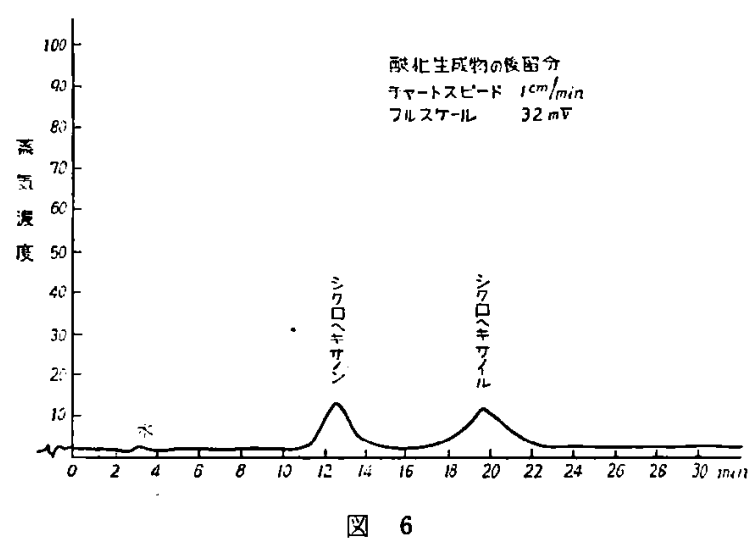

㘣 6

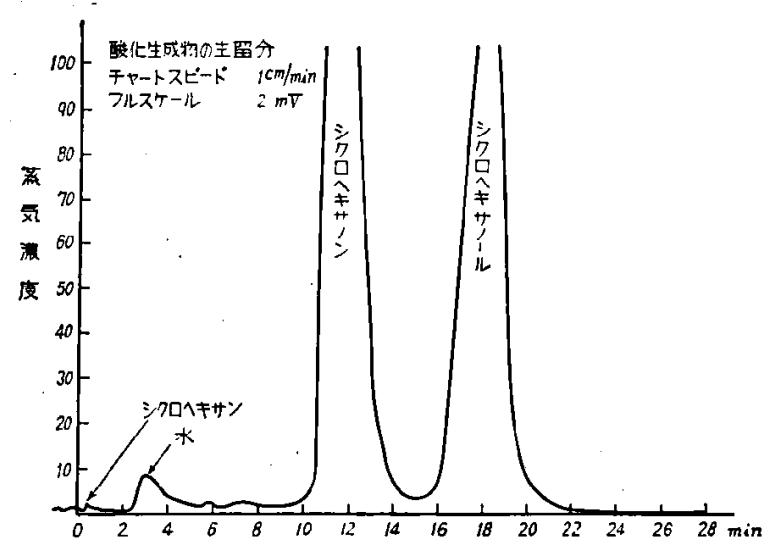

図 7

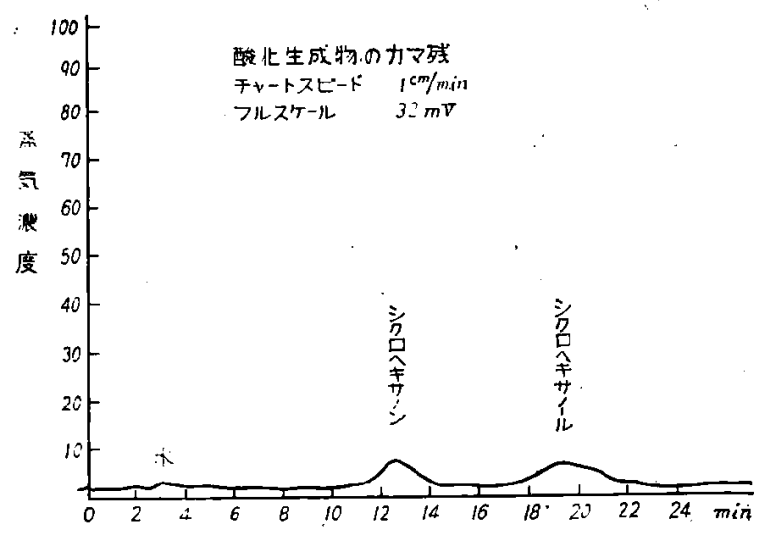

图 8

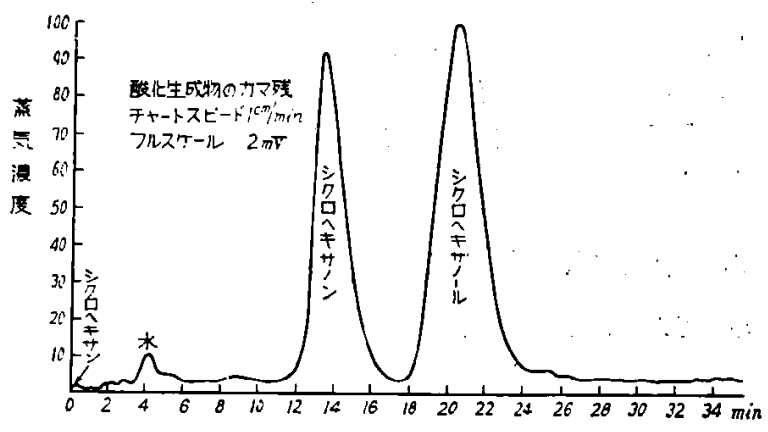

图 9

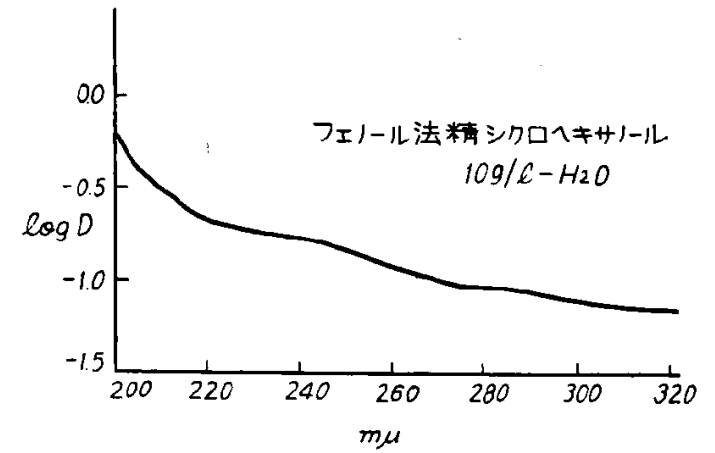

図 10

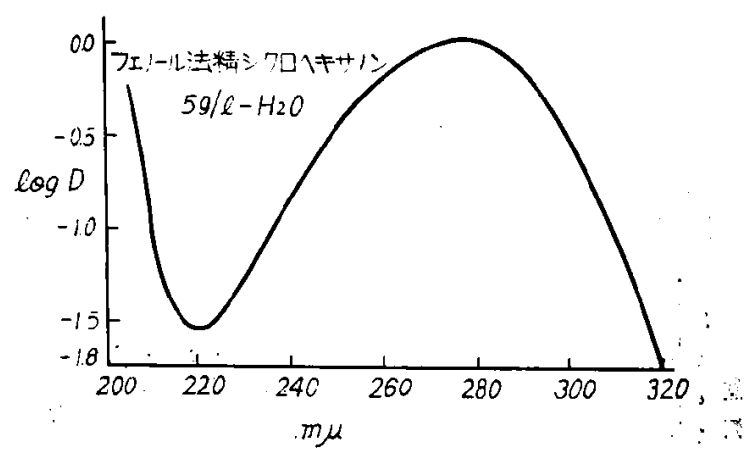

圆 11

化シクロヘキサノン中に特異な吸収があらわれると考えて矛盾 が起らない。

\section{4 総括}

シクロヘキサンの液相酸化によって得られたシクロヘキサ， ン・シクロヘキサノールの品質をガスクロマトグラフならびK 


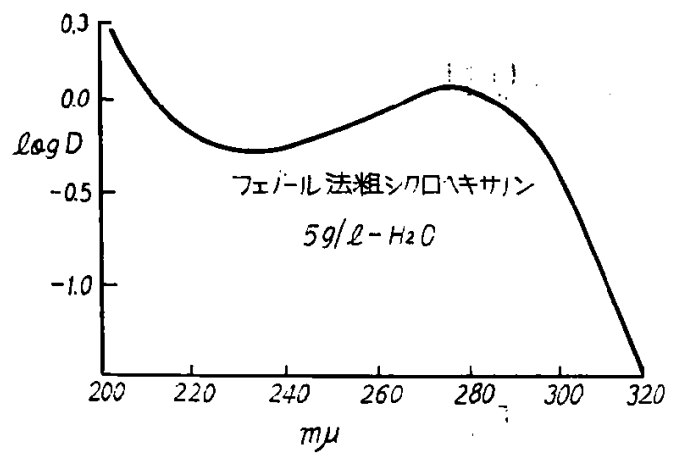

因 12

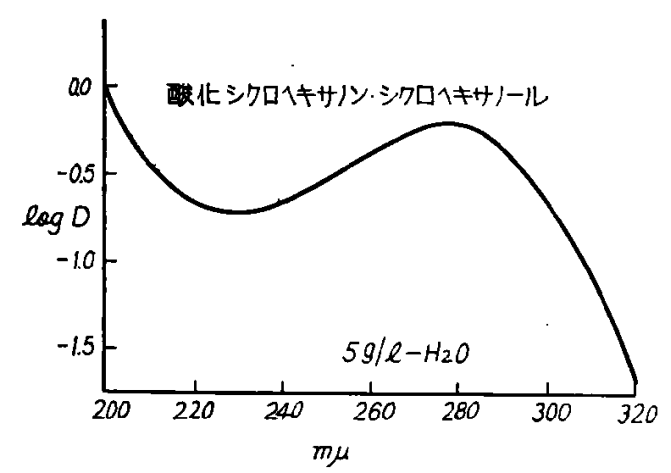

因 13

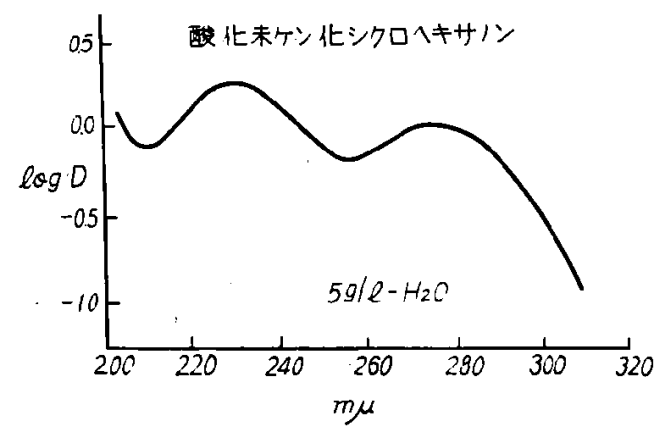

因 14

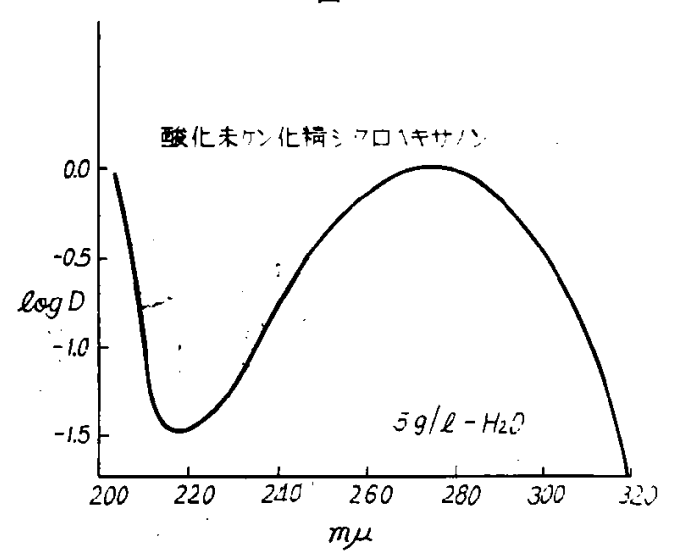

图 15

紫外部吸収スペクトルによってしらべ,フェノール法によって 得られたシクロヘキサノン・シクロヘキサノールと比較した。 ガスクロマトグラフでは顕著な不純物を確珰しえなかったが紫 外部忣収スペクトルでは未ケン化シクロヘキサノンに $230 \mathrm{~m} \mu$ の波長に特異吸収を示す不純物が検出された。これはエステル 価, 沸点詁よびエステル類の吸収スペクトルから類推しシクロ

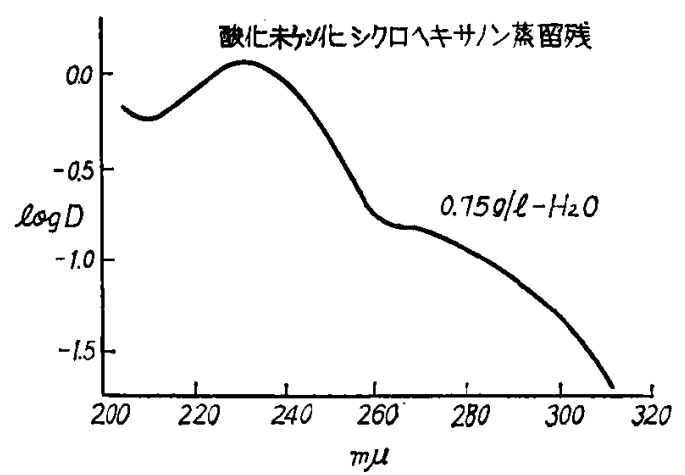

図 16

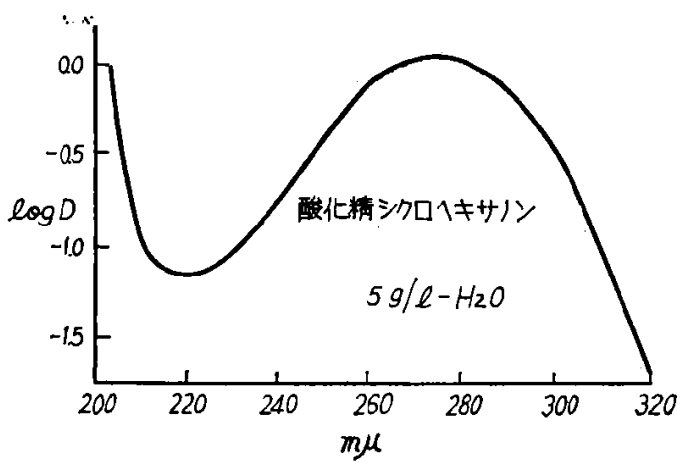

图 $\quad 17$

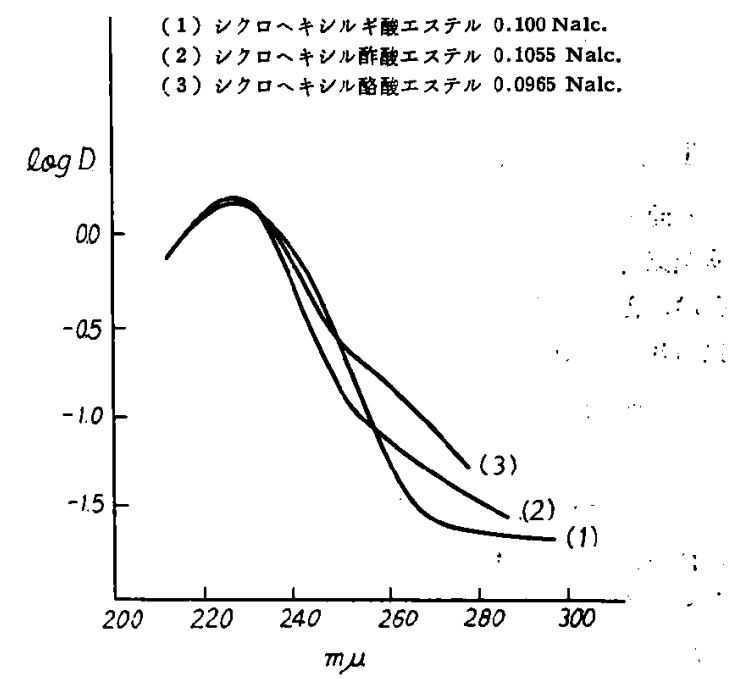

図 18

ヘキサノールの有機酸エステルではないかと考える。

ケン化を行なった酸化精シクロヘキサノンとフェノ一ル法精 シクロヘキサノンの吸収スペクトルは全く同じであった。ゆえ 飞筆者はシクロヘキサンの酸化によってとーカプロラクタムの 原料便用するシクロヘキサノン・シクロヘキサノールを製造 する場合, 酸化生成物を十分ヶン化し, 精密蒸留すれは徒来法 と同一品賀のものが得られることを確認した。

䅂りに本研究の発表を許可された会社当局ならびに研究の遂 行にあたり御援助いただいた当社ラクタム工場長坂倉駿一氏に 厚く感謝の意を表す。

$$
\text { 引用文 献 }
$$

1) 松波, 石油誌， B，(8)，620 (1961).

2) 日特公 $32-3971,32-6263,35-10614$ 